\title{
Geophysical and Borehole Studies for Optimum Drilling Depth and Groundwater Yields in a Typical Basement Terrain, South-western Nigeria
}

\author{
Muraina Zaid MOHAMMED. \\ Reader - Associate Professor \\ Department of Earth Sciences \\ Adekunle Ajasin University \\ Akungba-Akoko, Ondo State, Nigeria
}

\begin{abstract}
This study embraced the integration of 20 vertical electrical sounding (VES) and 15 borehole log datasets to determine optimum drilling depth and yields of boreholes in part of Akungba - Akoko, southwestern Nigeria. Resistivity soundings interpretation was aided by borehole litho-geologic information. Results revealed line-to-line correlation of three-five distinct subsurface geological/geoelectrical profiles to include; the topsoil, sandy/clayey weathered/partially weathered basement, fractured basement/fresh basement. The thickness and resistivity of the weathered basement column ranged between $1.9-15.8 \mathrm{~m}$ and 26 $579 \mathrm{ohm}-\mathrm{m}$ respectively. Regoliths, with a mean thickness of $9.97 \mathrm{~m}$ (approximately $10 \mathrm{~m}$ ), constituted thin aquitards developed on the basement. The combination of regoliths and the near-surfaced interbedding multiple thin layers of the fractured basement up to $30 \mathrm{~m}$ depths gave lower yields of less than $1.0 \mathrm{l} / \mathrm{s}$ to shallow boreholes. These drilled depths were those constrained at the instance of the poor index of lithologies exhibited by the sounding results, thus rendering the thin fractured beds undifferentiated from the thick resistive basement. Depths for high groundwater yields of $1.15-2.56 \mathrm{l} / \mathrm{s}$ were recorded for deeper borehole depths of $46-70 \mathrm{~m}$, with a mean of $55.3 \mathrm{~m}$. It can therefore be concluded that optimum groundwater yields not less than $2.0 \mathrm{l} / \mathrm{s}$ were recorded for boreholes that took full advantage of the weathered lithology and structures at a deeper depths of $60-65 \mathrm{~m}$. The study further asserts that beyond the mean depth of $55.3 \mathrm{~m}$, the deposits become more compacted, low fracture density with groundwater yields wholly retarded, thereby leaving the optimum drilling depth to $70 \mathrm{~m}$, as the target of most groundwater prospects for optimum yields of deeper boreholes in the area.
\end{abstract}

Key Words: Aquitard, Borehole Lithological Log, Correlation, Fractures, Resistivity, Groundwater Yields.

\section{INTRODUCTION}

Integration of borehole lithological logs and vertical electrical soundings remains a need-driven measure and a significant tool for optimizing exploration programme and borehole water yields in any groundwater project. Aside the above, the determination of the distributions of physical properties at depths which reflect the local subsurface geology may be projected to guide borehole drilling programme. However, the dearth of lithological logs to guide exploratory works is a common phenomenon arising from poor data gathering/database management and of course, expensive cost of drilling programme in most developing countries of the world. Lithological logs, therefore, provide exact subsurface information only at discrete locations while the geo electrical resistivity tool, VES specifically, unmasks resistivity contrast between saturated zone of the regoliths /fractured column and the unsaturated basement unit or bedrock in a typical basement terrain.

Vertical electrical sounding measures ground resistivity arising from the resulting potentials or voltages developed when current is introduced into the ground. Thus, this provides information on resistivity contrast and existence of a shallow and deep seated aquifer in known water bearing areas yet to be fully explored. The technique, therefore, constitutes a reliable means capable of delineating local features of potential interest such which include but not limited to subsurface fault/fissure/shear zones, geologic/geo electric sequences, depth to bedrock, weathered bedrock depressions, areal and depth extent/estimate of the saturated aquifers, for which general hydro geologic conditions/aquifer zones may be appraised for borehole water supply schemes. The 
above is notably supported by earlier workers [1-12], whose findings have described the discontinuous nature of the basement terrain aquifers as reason for a sparse and limited distribution of groundwater occurrence and yields.

Borehole lithologic log is a measure of the physical and structural properties of geologic formations down depth. It involves a careful record or logging/sampling of bailed out cuttings of the various geologic formations encountered at depths. The record of the penetration rate coupled with the physical properties of each formation encountered as drilling progresses enables proper positioning of the sequence of occurrence of the lithology [13]. This constitutes the borehole lithological log or simply the drillers' $\log$.

The basement complex of southwestern Nigeria, of which Akungba Akoko belongs, has undergone severe tectonic deformation over the geologic past, resulting in various degrees of fracturing and folding [14]. The area is dominated by lowlying and domy hills of crystalline rocks which have made groundwater prospect difficult, thereby impacting negatively the socio-economic life. In the light of the above, Akungba - Akoko remained one of the targets of the Ondo state government water project scheme in the year between 1999 - 2004. The town witnessed a tremendous attention of the state government in area of borehole water construction scheme arising from the relocation of the state owned University to the town. The continued exploitation of groundwater within the physiographic province in Akungba, therefore, requires integration of borehole information and predrilling geophysical survey. This is significant in view of not only for the more groundwater resource exploratory activities to come but also ambiguities found inherent in interpretation results of VES and its poor index of lithology due to significant overlap in the range of resistivity values for different lithologic materials. However, the dearth of borehole information coupled with the complex nature of the geology in this area compromised the optimum yields of the earlier drilled boreholes. General failure rate of boreholes was high in most places due to the termination of borehole depths within veneer of the weathered materials and/or the thin overburden cover or within the thin aquitard developed on basement rock [15-16]. Boreholes sunk are failed when little or no water is abstracted via pumping as soon as they are constructed while many others yielded considerably low for the envisaged average expected in the area.

In the light of the growing demands for groundwater and the renewed efforts to make water supplies available by private/government agencies, this present study is therefore, significant. Records of the few boreholes within the study area and those within the close proximity of the University campus abound in literature [17] and [18] are carefully selected and made significant as controls for this study. Analysis and correlation of VES and borehole lithological datasets will optimize groundwater exploration programme by maximizing the rate of ground coverage and minimizing the drilling of abortive boreholes. The synthesis of various drillers' logs and/or the existing borehole inventories with resistivity data has been found as a useful tool to unveil the key subsurface uncertainties and challenges inherent in judging the drilling works solely from geoelectric perspective. Knowledge of groundwater conditions can be derived optimally, in hydrogeologically difficult terrain for which Akungba areas is known, when two or more datasets; borehole litho-geological framework as well as the geophysical parameters, are properly applied and correlated. Integration is, therefore, a key to any drilling decision for productive and sustainable wells/boreholes in the area and may contribute to the overall success rate of delineating long-term productive boreholes and water wells for improved potable domestic water supplies and local economy.

\subsection{Description of the Study Environment}

The study area forms the northern part of Akungba-Akoko (Figure 1). The area constitutes the landmass comprising Akua, Okusa, Igbelu and Ibaka Quarters and Adekunle Ajasin Campus and is inhabited by student's populace, of over 70 percent of the 25,000 students' populations of the Adekunle Ajasin University, Akungba - Akoko. The area occupies part of the northern half of EastWest elongated lowland that is bounded in the north and south by basement ridges. It lies on latitudes $7^{0} 27^{1} \mathrm{~N}$ and $7^{0} 28^{1} \mathrm{~N}$ and longitude $5^{0} 44^{1} 56^{11} \mathrm{E}$ and $5^{0} 45^{1} \mathrm{E}$. It is situated in Akoko Southwest Local Government Area of Ondo State, Nigeria and covers an areal extent of about $2.5 \mathrm{~km}^{2}$. The study area is accessible via good network of motorable roads. A major tarred highway that divides the town serves as the only link between Owo and Ikare towns. Other tarred and untarred roads found around connect one quarter to another, thus providing good accessibility to most parts of the area. 


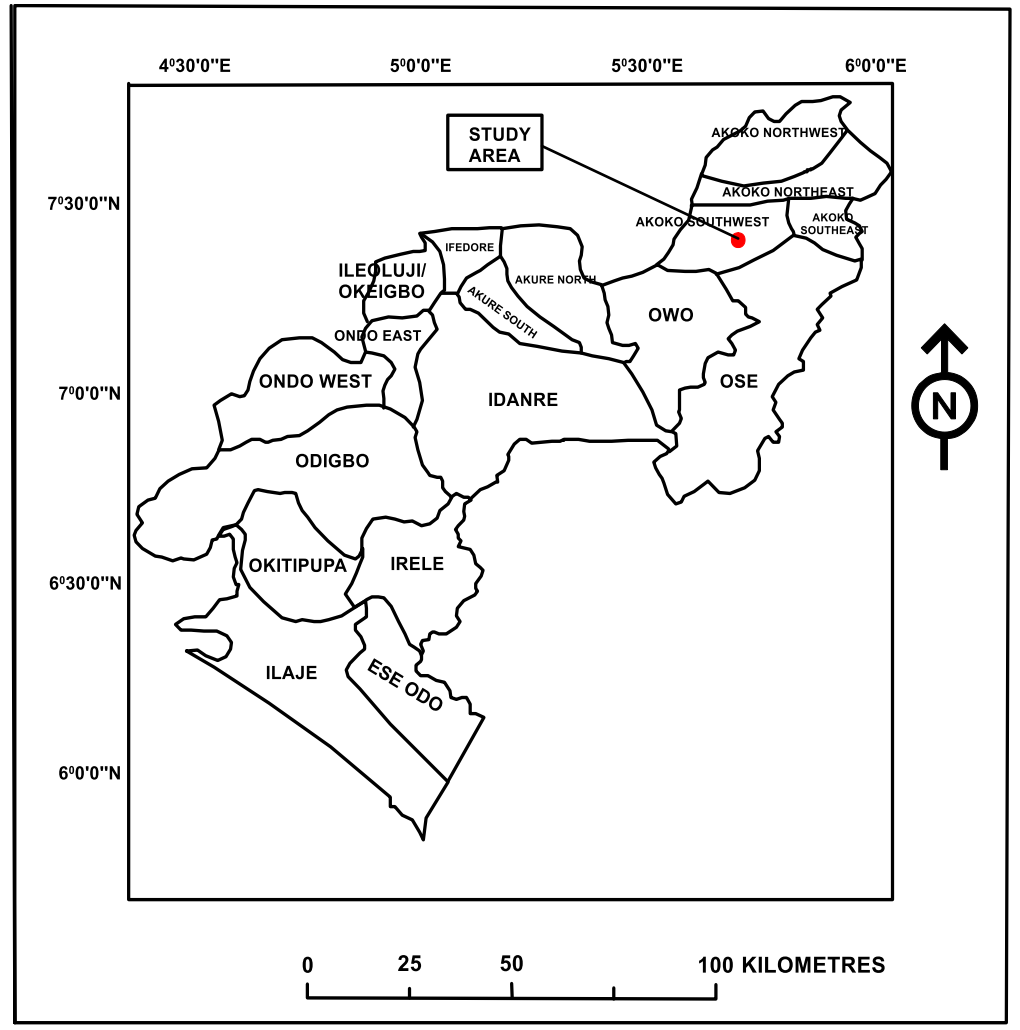

Figure 1: Map of Ondo state showing the location of Akungba Akoko

Generally, the relief of the area is between 350 and $700 \mathrm{~m}$ above sea level (Figure 2), comprising lowlands and rugged hills and typified by anticlinal and synclinal structures [19]. The area is located within the tropical region of Nigeria, with an average annual temperature of approximately $22^{\circ} \mathrm{C}$. This region is characterized by two contrasting seasons: rainy season (March to early November) and dry season (November to March). The mean annual rainfall ranges between 1270 and $1524 \mathrm{~mm}$ [19]. The area is largely drained by River Alatan bifurcating the town into two halves- northern and southern halves, trending approximately NESW direction. The tributary streams take their courses from the surrounding high, dissected and resistant hills to the E-W trending low lying platforms and valleys. The drainage pattern is generally dendritic, suggesting tectonic influence on flow pattern.

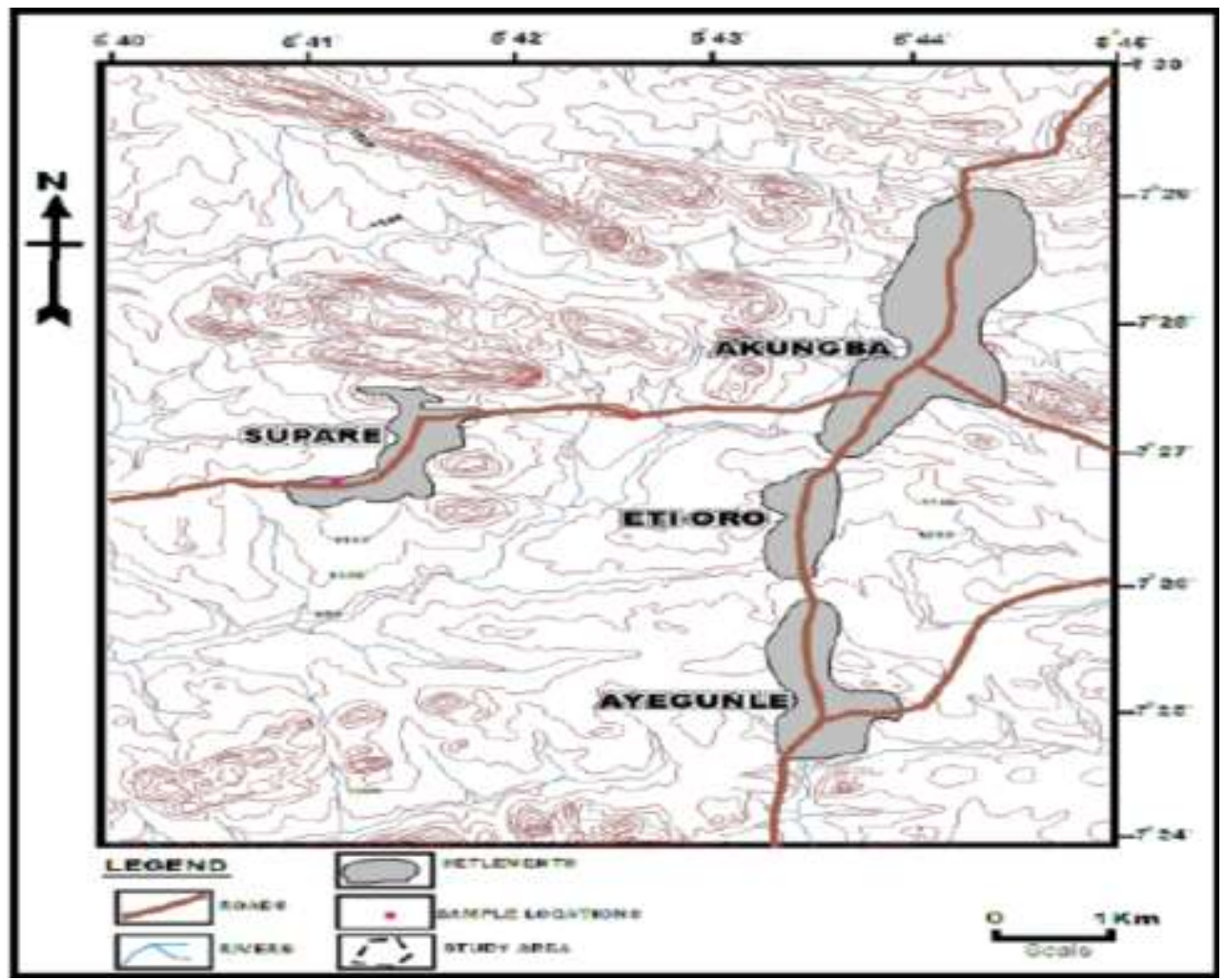

Figure2. Topographic map of the study area and its environs [19] 
The town is underlain by Precambrian Basement rocks of the southwestern Nigeria with migmatites and gneiss constituting the two dominant rock types [20] and [21] in Figure 3. The rocks outcrop as lowland and domy ridges trending E-W. The rock units which are characteristically hard, compact, unsaturated and impermeable are shallow with thin overburden cover or exposed as outcrops in many places in the area.

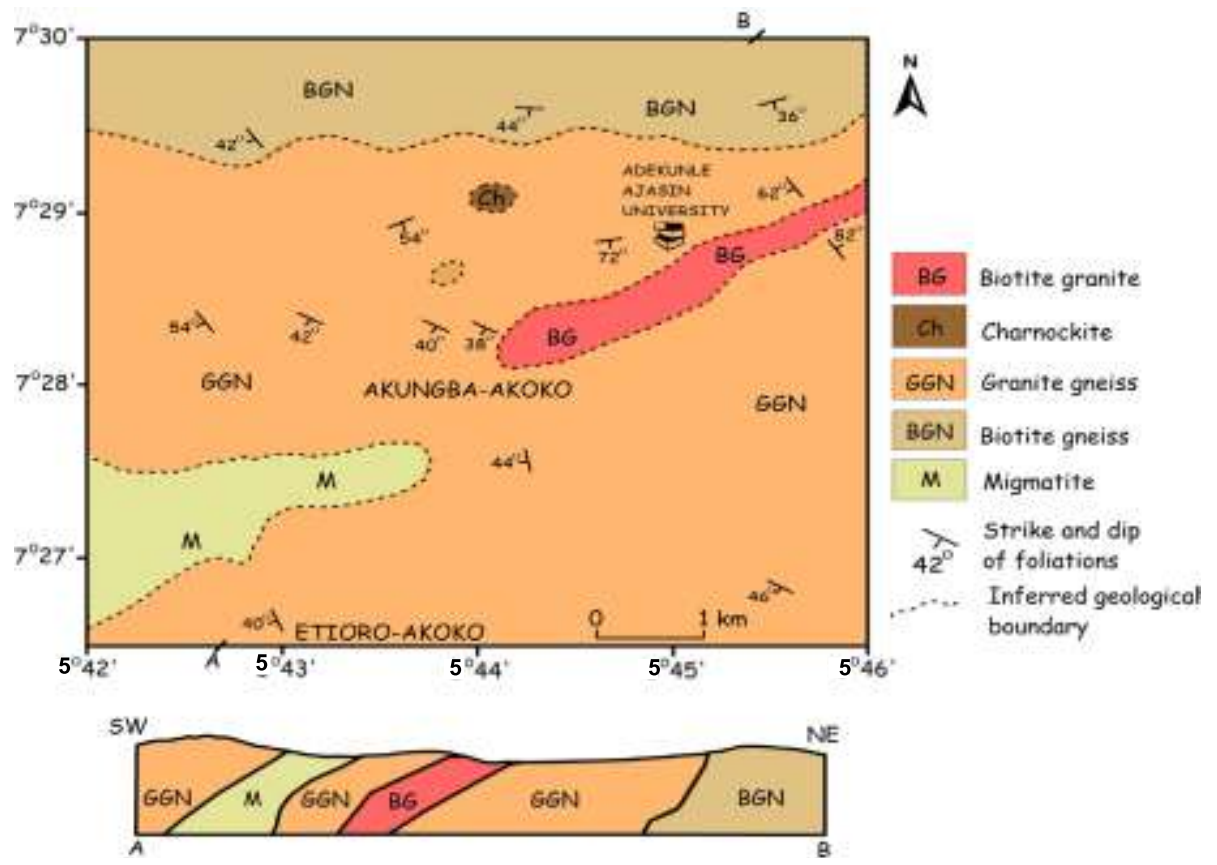

Figure 3. Geological map and schematic cross-section of Akungba-Akoko area [21]

\subsection{MATERIALS AND METHODS}

Nine (9) Wenner and Eleven (11) Schlumberger vertical electrical soundings datasets were obtained across the area (Figure 4 a). The VES stations for the prospective borehole sites were selected with regards to demand for groundwater supplies in the northern part playing a host community to the University. Geonic EM 34-3 equipment with a co-planar loop system was used for reconnaissance exploration to aid the selection of sounding stations particularly, for the Schlumberger soundings, in the physiographic area of the campus. A range of conductivity between $8-13 \mathrm{mSm}$ was considered satisfactory for the selections on the field. The elevations of the VES stations varied from $350 \mathrm{~m}$ within the town to a maximum of $392 \mathrm{~m}$ on campus. A typical four collinear arrays system as applicable to arrays employed was adopted (Figure $4 \mathrm{~b}$ ). The inter-electrode spacings $(\mathrm{AB} / 3$ and $\mathrm{AB} / 2$ ) varied from 1 to $62 \mathrm{~m}$ and 1 to $100 \mathrm{~m}$ with maximum spread lengths of 134 and $200 \mathrm{~m}$ respectively. ABEM SAS 300 resistivity meter was used for the field measurements of the resistance for each movement of current electrode positions. The product of each value of the resistance $(\mathrm{R})$ and the corresponding value of the geometric factor of the array at the current electrode position gave the measured ground apparent resistivity at the sounding stations for the two arrays. 


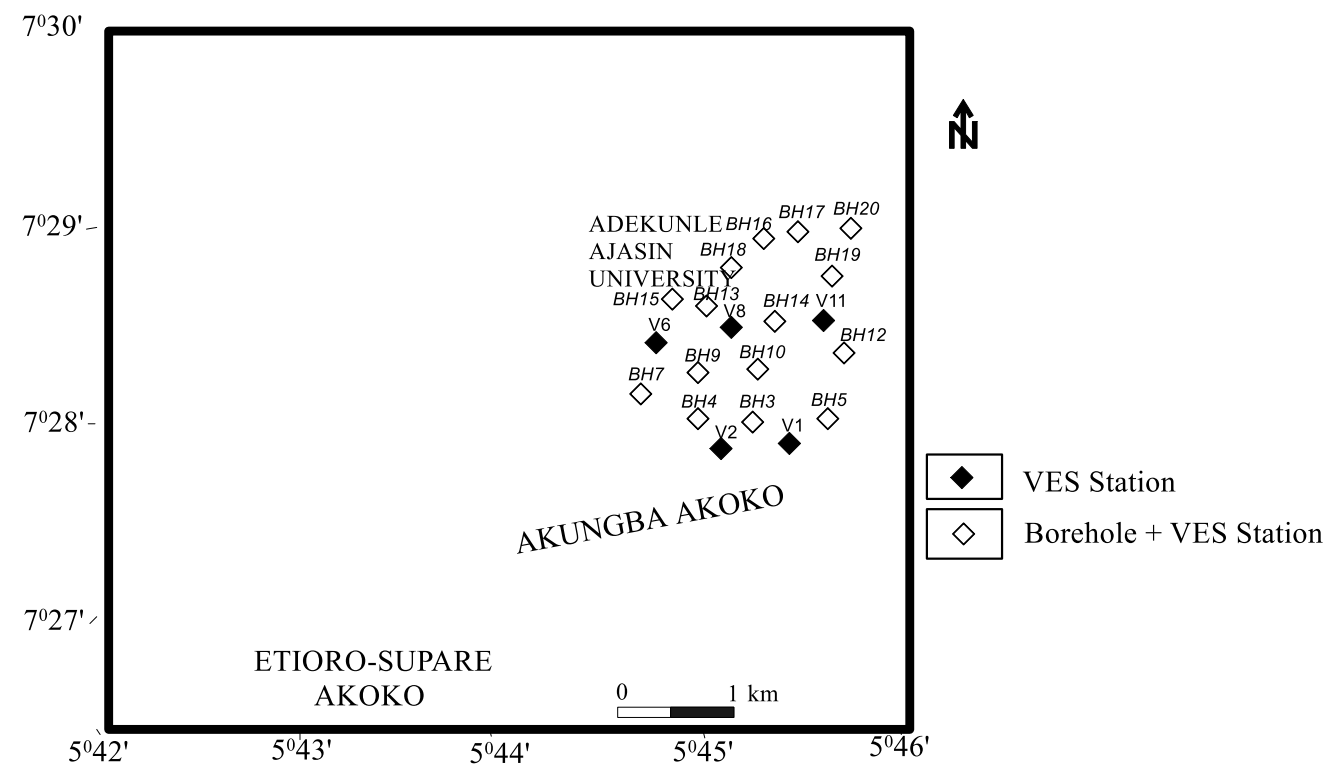

(a) Location of Borehole and Geoelectric data points

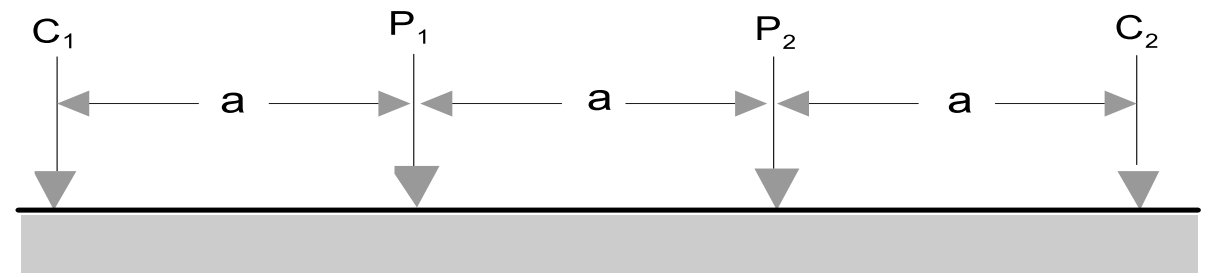

(b) Typical four array in resistivity survey

Figure 4: Data coordinates and acquisition techniques

The vertical electrical sounding data were presented as field or depth sounding curves. The curves were obtained by plotting the apparent resistivity $\left(\rho_{\mathrm{a}}\right)$ data against electrode spacing $(\mathrm{AB} / 3$ and $\mathrm{AB} / 2$ in metres) on a log - log graph paper. Logarithm scale was used on both axes due to large variation in apparent resistivities. The plots were connected to obtain a smooth curve at each station. The VES field curves were interpreted quantitatively to obtain layer parameters. The interpretation which involved partial curve matching technique was constrained using existing drill hole information, particularly for the 11 Schumberger soundings. The layer parameters of the individual VES were finally obtained using the 1D inversion of the WinResist Software.

Borehole lithological log data from existing five boreholes constructed by Ondo State Government - (WATSAN) between 2002 2004, and additional ten log data carefully monitored and selected from new drill holes at the University campus between 2010 2019 constitute a total of fifteen borehole datasets available for integration and deduction purposes. Other borehole inventories employed included borehole yields, fracture frequency, drilling depths and borehole static water levels. However, the yields of the new drills were determined using a known volume in litres and a stop-watch timing device. Boreholes were percussion drilled with hammering tungsten-carbide bits and air rotary - compressed to remove drill cuttings or rock chips from the holes to the surface. The boreholes were subsequently installed with $0.75-1.0 \mathrm{Hp}$ rated submersible pumps and $150 \mathrm{~mm}$ (6 inches) / $100 \mathrm{~mm}$ (4 inches) diameter casing and screen of the upper two geologic layers. Timing of a continuous pumping for 1000 litres volume was done and recorded to determine the yields for the new boreholes in litre per second (1/s).

\subsection{RESULTS AND DISCUSSION}

\subsection{Geo-electric and Borehole Characterization}

Typical sounding curve and its geoelectric parameters in 1- D inversion are shown in Figure 5. Generally, the sounding curves show a steeply rising terminal branch indicating an increase in apparent resistivity values with depth at large electrode spacings due to the effect of highly resistive basal bedrock. Change in gradients of the curves or kinks in sounding curves are observed to indicate change in subsurface geological sequences at near surface and fracture depths. The summary of the layer parameters of the type - curves iterated are shown in Table 1. 
In Table 1 ( $\mathrm{a}$ and b), HA and HKH-type curves are prevalent in the area and account for about $25 \%$ and 20\%, while $\mathrm{H}, \mathrm{QH}$ and KHKH account for $10 \%$ each, and the remaining other five type curves contribute 5\% each. On the basis of similar diagnostic geoelectric features, the type curves are divided into three groups [22]. Group 1 comprises $\mathrm{H}$ and QH- type curves. Group 2 consists of A, HA, HAA and KHA - type curves and Group 3 consists of HKH, QHKH and KHKH - type curves. Generally, the groups consist of the topsoil, weathered/fractured bedrock which constitute(s) aquitards/aquifer unit(s), follow by the basal fresh bedrock. A four and five-layered geoelectric sequence is obtained in in the groups 2 and 3, where additional layer composed of clayey horizon usually underlies the topsoil, while the weathered/partially weathered basement in these groups is thick enough to be differentiated. In the five layered geologic models as observed from the field data and iterated curves, fracture depths particularly at large electrode spacings show small drop in gradients as kinks. This thus implies that, the fracture intersections at depths appreciably affects the sounding curves' geometry and may be mapped as a distinct layer overlying and/or interbedding the fresh bedrock.

The geologic sequences and intervals at depths were validated by the penetration rate of the drilling and/or borehole lithological $\log$ samples. The sequence recorded comprised topsoil of variable moisture, sandy clay/clayey weathered layer, partially weathered/fractured basement and fresh basement/bedrock. The topsoil unit covers an interval of about $2-3 \mathrm{~m}$. The clay/sandy clay/sandy unit is found within the interval of about 11 to $52 \mathrm{~m}$ which corresponds to the weathered/partially weathered/fractured basement columns. The unit consists of about 50-60\% quartz of all sizes and characterized by mixture of gravels, sands, silts and clays.

Of particular importance is the partially weathered basement layer directly underlies the weathered basement and thin fracture columns. In most places these layers are subdued by the thickness of a more resistivity basement column and mistakenly not considered for prospect in some cases. However, where a fracture at depth is supported by these several sharp contacts and thin structures as applicable in the study is usually expected to enhance aquifer thickness,

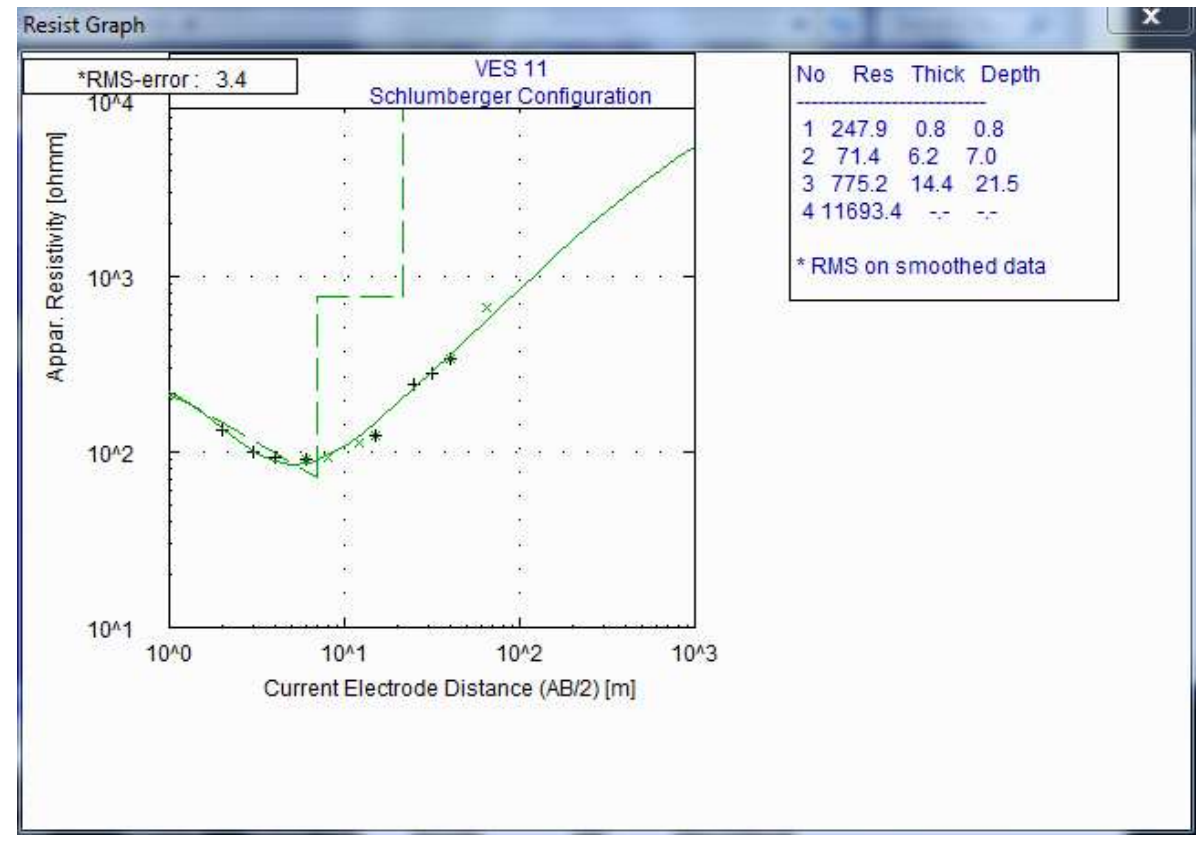

Figure 5. Typical HA - type curve in the study area

Table $1 \mathrm{a}$ a. Summary of 1-D Inversion of the Wenner sonndings and borehole lithological characteristics

\begin{tabular}{|c|c|c|c|c|c|}
\hline $\begin{array}{l}\text { BH/VES } \\
\text { No }\end{array}$ & $\begin{array}{l}\text { Layer } \\
\text { thickness } \\
\text { interval }(\mathrm{m})\end{array}$ & $\begin{array}{l}\text { Layer } \\
\text { resistivity } \\
\text { (ohm-m) }\end{array}$ & $\begin{array}{l}\text { BH } \\
\text { depth } \\
\text { interval } \\
(\mathrm{m})\end{array}$ & Description of lithologies & Remarks \\
\hline VES 1 & $\begin{array}{l}0-0.5 \\
0.5-2.5\end{array}$ & $\begin{array}{l}1098 \\
229 \\
1862\end{array}$ & $\begin{array}{l}- \\
- \\
-\end{array}$ & $\begin{array}{l}\text { Topsoil } \\
\text { Weathered basement } \\
\text { Fresh basement }\end{array}$ & $\begin{array}{l}\mathrm{H}-\text { type curve } \\
\text { Not Drilled }\end{array}$ \\
\hline VES 2 & $\begin{array}{c}0-0.8 \\
0.8-2.7 \\
2.7-10.3\end{array}$ & $\begin{array}{l}277 \\
113 \\
132 \\
\end{array}$ & $\begin{array}{l}- \\
- \\
-\end{array}$ & $\begin{array}{l}\text { Topsoil } \\
\text { Weathered basement } \\
\text { Fractured basement }\end{array}$ & $\begin{array}{l}\text { HA - type curve } \\
\text { Not Drilled }\end{array}$ \\
\hline
\end{tabular}


International Journal of Advances in Scientific Research and Engineering (ijasre), Vol 8 (2), February -2022

\begin{tabular}{|c|c|c|c|c|c|}
\hline & & 886 & - & Fractured basement & \\
\hline VES 3 & $\begin{array}{l}0-1.1 \\
1.1-15.8 \\
15.8-31.5\end{array}$ & $\begin{array}{l}413 \\
88 \\
514 \\
2294\end{array}$ & $\begin{array}{c}0-1 \\
1-16 \\
16-32 \\
\quad-\end{array}$ & $\begin{array}{l}\text { Topsoil } \\
\text { Clayey weathered basement } \\
\text { Fractured basement } \\
\text { Fresh basement }\end{array}$ & $\begin{array}{l}\text { HA - type curve. } \\
\text { Borehole Productive } \\
\text { Terminated within } \\
\text { fractured basement }\end{array}$ \\
\hline VES 4 & $\begin{array}{l}0-1.2 \\
1.2-3.6 \\
3.6-6.1 \\
6.1-14.1\end{array}$ & $\begin{array}{l}226 \\
127 \\
305 \\
93 \\
704 \\
\end{array}$ & $\begin{array}{c}0-2 \\
2-14 \\
14-32 \\
-- \\
- \\
\end{array}$ & $\begin{array}{l}\text { Topsoil } \\
\text { Weathered basement } \\
\text { Fractured basement }\end{array}$ & $\begin{array}{l}\text { HKH - type curve. } \\
\text { Borehole Productive } \\
\text { Terminated within } \\
\text { fractured zone. }\end{array}$ \\
\hline VES 5 & $\begin{array}{l}0-0.2 \\
0.2-3.8 \\
3.8-5.9 \\
5.9-24.4\end{array}$ & $\begin{array}{l}295 \\
99 \\
407 \\
54 \\
46681\end{array}$ & $\begin{array}{c}0-1 \\
1-6 \\
6-30 \\
-- \\
-\end{array}$ & $\begin{array}{l}\text { Topsoil } \\
\text { Clayey weathered basement } \\
\text { Fractured basement } \\
\text { - } \\
\text { Fresh basement }\end{array}$ & $\begin{array}{l}\text { HKH - type curve. } \\
\text { Borehole Productive } \\
\text { Terminated within } \\
\text { fresh basement. }\end{array}$ \\
\hline VES 6 & $\begin{array}{l}0-1.1 \\
1.1-3.0 \\
3.0-12.5\end{array}$ & $\begin{array}{l}194 \\
188 \\
26 \\
938\end{array}$ & $\begin{array}{l}- \\
- \\
-\end{array}$ & $\begin{array}{l}\text { Topsoil } \\
\text { Weathered basement } \\
\text { Clayey weathered basement } \\
\text { Fractured basement }\end{array}$ & $\begin{array}{l}\mathrm{QH} \text { - type curve } \\
\text { Not Drilled }\end{array}$ \\
\hline VES 7 & $\begin{array}{l}0-2.1 \\
2.1-8.5 \\
8.5-15.0\end{array}$ & $\begin{array}{l}117 \\
65 \\
220 \\
1889\end{array}$ & $\begin{array}{c}0-2 \\
2-8 \\
8-32 \\
--\end{array}$ & $\begin{array}{l}\text { Topsoil } \\
\text { Clayey Weathered basement } \\
\text { Fractured basement } \\
\text { Fresh basement }\end{array}$ & $\begin{array}{l}\text { Productive } \\
\text { HA - type curve. } \\
\text { Borehole Productive } \\
\text { Terminated within } \\
\text { fresh basement }\end{array}$ \\
\hline VES 8 & $\begin{array}{l}0-1.2 \\
1.2-14.8\end{array}$ & $\begin{array}{l}85 \\
92 \\
9718\end{array}$ & $\begin{array}{l}- \\
- \\
-\end{array}$ & $\begin{array}{l}\text { Topsoil } \\
\text { Clayey weathered basement } \\
\text { Fresh basement }\end{array}$ & $\begin{array}{l}\text { Not Drilled } \\
\text { A - type curve }\end{array}$ \\
\hline VES 9 & $\begin{array}{l}0-1.9 \\
1.9-7.7\end{array}$ & $\begin{array}{l}83 \\
55 \\
843\end{array}$ & $\begin{array}{l}0-2 \\
2-10 \\
10-30 \\
\quad-\end{array}$ & $\begin{array}{l}\text { Topsoil } \\
\text { Clayey weathered basement } \\
\text { Fractured basement } \\
\text { Fresh basement }\end{array}$ & $\begin{array}{l}\mathrm{H} \text { - type curve } \\
\text { Borehole Productive } \\
\text { Terminated within } \\
\text { fractured basement }\end{array}$ \\
\hline
\end{tabular}

Table $1 \mathrm{~b}$. Summary of 1-D Inversion Schlumberger VES and borehole lithological characteristics

\begin{tabular}{|c|c|c|c|c|c|}
\hline $\begin{array}{l}\text { BH/VES } \\
\text { No }\end{array}$ & $\begin{array}{l}\text { Layer } \\
\text { thickness } \\
\text { interval }(\mathrm{m})\end{array}$ & $\begin{array}{l}\text { Layer } \\
\text { resistivity } \\
(\mathrm{ohm}-\mathrm{m})\end{array}$ & $\begin{array}{l}\text { BH } \\
\text { depth } \\
\text { interval } \\
\text { (m) }\end{array}$ & Description of lithologies & Remarks \\
\hline VES 10 & $\begin{array}{l}0-1.0 \\
1.0-4.5 \\
4.5-12.3 \\
12.3-31.4 \\
31.4-70.8\end{array}$ & $\begin{array}{l}44 \\
79 \\
29 \\
185 \\
126 \\
10019\end{array}$ & $\begin{array}{c}0-2 \\
2-12 \\
12-70 \\
- \\
- \\
-\end{array}$ & $\begin{array}{l}\text { Topsoil } \\
\text { Clayey weathered basement } \\
\text { Fractured basement } \\
- \\
\text { - } \\
\text { Fresh basement }\end{array}$ & $\begin{array}{l}\text { KHKH - type curve. } \\
\text { Borehole Productive } \\
\text { Terminated within fractured } \\
\text { basement }\end{array}$ \\
\hline VES 11 & $\begin{array}{l}0-0.8 \\
0.8-7.0 \\
7.0-21.5\end{array}$ & $\begin{array}{l}248 \\
71 \\
775 \\
11693 \\
\end{array}$ & $\begin{array}{l}- \\
- \\
- \\
-\end{array}$ & $\begin{array}{l}\text { Topsoil } \\
\text { Clayey weathered basement } \\
\text { Fractured basement } \\
\text { Fresh basement }\end{array}$ & $\begin{array}{l}\text { HA - type curve } \\
\text { Not Drilled }\end{array}$ \\
\hline VES 12 & $\begin{array}{l}0-1.2 \\
1.2-3.5 \\
3.5-9.2 \\
9.2-16.7 \\
16.7-28.6\end{array}$ & $\begin{array}{l}450 \\
126 \\
58 \\
675 \\
182 \\
10287\end{array}$ & $\begin{array}{c}0-2 \\
2-16 \\
16-45 \\
45-55 \\
\quad-\end{array}$ & $\begin{array}{l}\text { Topsoil } \\
\text { Weathered basement } \\
\text { Fractured basement } \\
\text { - } \\
\text { - } \\
\text { Fresh basement }\end{array}$ & $\begin{array}{l}\text { QHKH - type curve } \\
\text { Borehole Productive } \\
\text { Terminated within fresh } \\
\text { basement }\end{array}$ \\
\hline VES 13 & $0-0.5$ & 65 & $0-2$ & Topsoil & $\mathrm{KH}$ - type curve \\
\hline
\end{tabular}


International Journal of Advances in Scientific Research and Engineering (ijasre), Vol 8 (2), February -2022

\begin{tabular}{|c|c|c|c|c|c|}
\hline & $\begin{array}{c}0.5-1.2 \\
1.2-9.7\end{array}$ & $\begin{array}{l}533 \\
77 \\
703\end{array}$ & $\begin{array}{c}2-10 \\
10-57 \\
--\end{array}$ & $\begin{array}{l}\text { Clayey weathered basement } \\
\text { Fractured basement } \\
\text { - }\end{array}$ & $\begin{array}{l}\text { Borehole Productive } \\
\text { Terminated within fractured } \\
\text { zone. }\end{array}$ \\
\hline VES 14 & $\begin{array}{l}0-0.6 \\
0.6-3.2 \\
3.2-11.1 \\
11.1-57.0\end{array}$ & $\begin{array}{l}23 \\
91 \\
28 \\
594 \\
10145\end{array}$ & $\begin{array}{l}0-2 \\
2-11 \\
11-60\end{array}$ & $\begin{array}{l}\text { Topsoil } \\
\text { Weathered basement } \\
\text { Fractured basement } \\
\text { - } \\
\text { Fresh basement }\end{array}$ & $\begin{array}{l}\text { KHA - type curve } \\
\text { Borehole Productive } \\
\text { Terminated within fractured } \\
\text { zone }\end{array}$ \\
\hline VES 15 & $\begin{array}{l}0-1.6 \\
1.6-7.5 \\
7.5-51.1 \\
51.1-93.8\end{array}$ & $\begin{array}{l}1304 \\
101 \\
1468 \\
463 \\
9894\end{array}$ & $\begin{array}{c}0-2 \\
2-7.5 \\
7.5-50 \\
50-70 \\
\quad-\end{array}$ & $\begin{array}{l}\text { Topsoil } \\
\text { Clayey weathered basement } \\
\text { Partially weathered } \\
\text { Fractured basement } \\
\text { Fresh basement }\end{array}$ & $\begin{array}{l}\text { HKH - type curve } \\
\text { Borehole Productive } \\
\text { Terminated within fractured } \\
\text { zone }\end{array}$ \\
\hline VES 16 & $\begin{array}{l}0-1.0 \\
1.0-7.5 \\
7.5-12.9 \\
12.9-32.3\end{array}$ & $\begin{array}{l}998 \\
276 \\
510 \\
974 \\
13292\end{array}$ & $\begin{array}{c}0-2 \\
2-14 \\
14-50\end{array}$ & $\begin{array}{l}\text { Topsoil } \\
\text { Sandy weathered basement } \\
\text { Partially weathered/ } \\
\text { Fractured basement } \\
\text { Fresh basement }\end{array}$ & $\begin{array}{l}\text { HAA - type curve } \\
\text { Borehole Productive } \\
\text { Terminated within fresh } \\
\text { basement. }\end{array}$ \\
\hline VES 17 & $\begin{array}{l}0-0.2 \\
0.2-0.9 \\
0.9-5.1 \\
5.1-14 \\
14-78.8\end{array}$ & $\begin{array}{l}96 \\
1520 \\
84 \\
579 \\
436 \\
10020\end{array}$ & $\begin{array}{l}0-2 \\
2-14 \\
14-30 \\
30-70\end{array}$ & $\begin{array}{l}\text { Topsoil (clayey/lateritic) } \\
\text { Weathered basement } \\
\text { Partially weathered/ } \\
\text { Fractured basement } \\
\text { - } \\
\text { Fresh basement }\end{array}$ & $\begin{array}{l}\text { KHKH - type curve } \\
\text { Borehole Productive } \\
\text { Terminated within fractured } \\
\text { basement. }\end{array}$ \\
\hline VES 18 & $\begin{array}{l}0-0.9 \\
0.9-7.2 \\
7.2-35.1\end{array}$ & $\begin{array}{l}395 \\
66 \\
628 \\
10175\end{array}$ & $\begin{array}{l}0-1 \\
1-8 \\
8-60 \\
--\end{array}$ & $\begin{array}{l}\text { Topsoil } \\
\text { Clayey weathered basement } \\
\text { Fractured basement } \\
\text { Fresh basement }\end{array}$ & $\begin{array}{l}\text { HA - type curve } \\
\text { Borehole Productive } \\
\text { Terminated within fresh } \\
\text { basement. }\end{array}$ \\
\hline VES 19 & $\begin{array}{l}0-0.5 \\
0.5-3.0 \\
3.0-11.3 \\
11.3-48.4\end{array}$ & $\begin{array}{l}447 \\
71 \\
412 \\
166 \\
10056\end{array}$ & $\begin{array}{l}0-1 \\
1-3 \\
3-10 \\
10-55 \\
-\end{array}$ & $\begin{array}{l}\text { Topsoil } \\
\text { Weathered basement } \\
\text { Partially weathered/ } \\
\text { Fractured basement } \\
\text { Fresh basement }\end{array}$ & $\begin{array}{l}\text { HKH - type curve } \\
\text { Borehole Productive } \\
\text { Terminated within fresh } \\
\text { basement. }\end{array}$ \\
\hline VES 20 & $\begin{array}{l}0-0.4 \\
0.4-5.9 \\
5.9-45.2\end{array}$ & $\begin{array}{l}552 \\
154 \\
133 \\
3458\end{array}$ & $\begin{array}{l}0-1.0 \\
1.0-6 \\
6-46 \\
-\end{array}$ & $\begin{array}{l}\text { Topsoil } \\
\text { Weathered basement } \\
\text { Fractured basement } \\
\text { Fresh Basement }\end{array}$ & $\begin{array}{l}\mathrm{QH} \text { - type curve } \\
\text { Borehole Productive } \\
\text { Terminated within fractured } \\
\text { basement }\end{array}$ \\
\hline
\end{tabular}

groundwater storage and yields. Resistivity values greater than $450 \mathrm{ohm}-\mathrm{m}$ may be attributed to this column. The thicknesses of the first upper two geoelectric layers show a fit and good line to line correlation with the borehole lithological logs (Figure 6). The correlation indicates a significant level of reliability of the estimates. Beyond this depth are intebedded thin of multiple fractures and large fracture basement zones. Although, the thin layered fractures are usually obscured, in most cases, on sounding curves due to the thick effect of more resistive basement column and poor index of lithogies.

Within geophysics and hydrogeologic inspections, resistivity and thickness thresholds of the regoliths and fracture depths may be considered as major key players in the selection of boreholes drill sites and depths. Modification of earlier works in a typical basement/sedimentary transition environment [23] and [13] is adopted to suite a rational choice of prospective drill sites. Therefore, the choice of drill sites with improved yields may have depended on the following: (i). VES stations with a threshold weathered/partially weathered thickness not less than $10 \mathrm{~m}$ and fracture depth sections with a drilling depth $>40 \mathrm{~m}$ and resistivity $>250 \mathrm{ohm}-\mathrm{m}$ are considered as priority sites, while the VES stations with lower thickness of regoliths $<10 \mathrm{~m}$ with drilling depth $<30 \mathrm{~m}$ and high resistivity $<250$ or $>250 \mathrm{ohm}-\mathrm{m}$ are considered as wildcat and outside choices.

Table 2 presents the outlook of 15 borehole inventories to include borehole depths, fracture depths, depths to rockheads borehole yield estimates/performances with continuous pumping at different rockheads. The table helps to understand the sections of 
hydrogeologic importance for excellent borehole design decision and yield enhancement. The drilling depths of borehole vary from $24-70 \mathrm{~m}$.

Boreholes located within the weathered basement that terminated at shallow depths (24 - $30 \mathrm{~m}$ ) presumably a rockhead gave lower yields in $\mathrm{BH} 3-\mathrm{BH} 5, \mathrm{BH} 7$ and $\mathrm{BH}$ 9. On the other hand, those terminated to take advantage of the partially weathered/fractured aquifers terminated at rockheads $(46-70 \mathrm{~m})$, gave higher yields of between $1.15-2.56 \mathrm{l} / \mathrm{s}$.

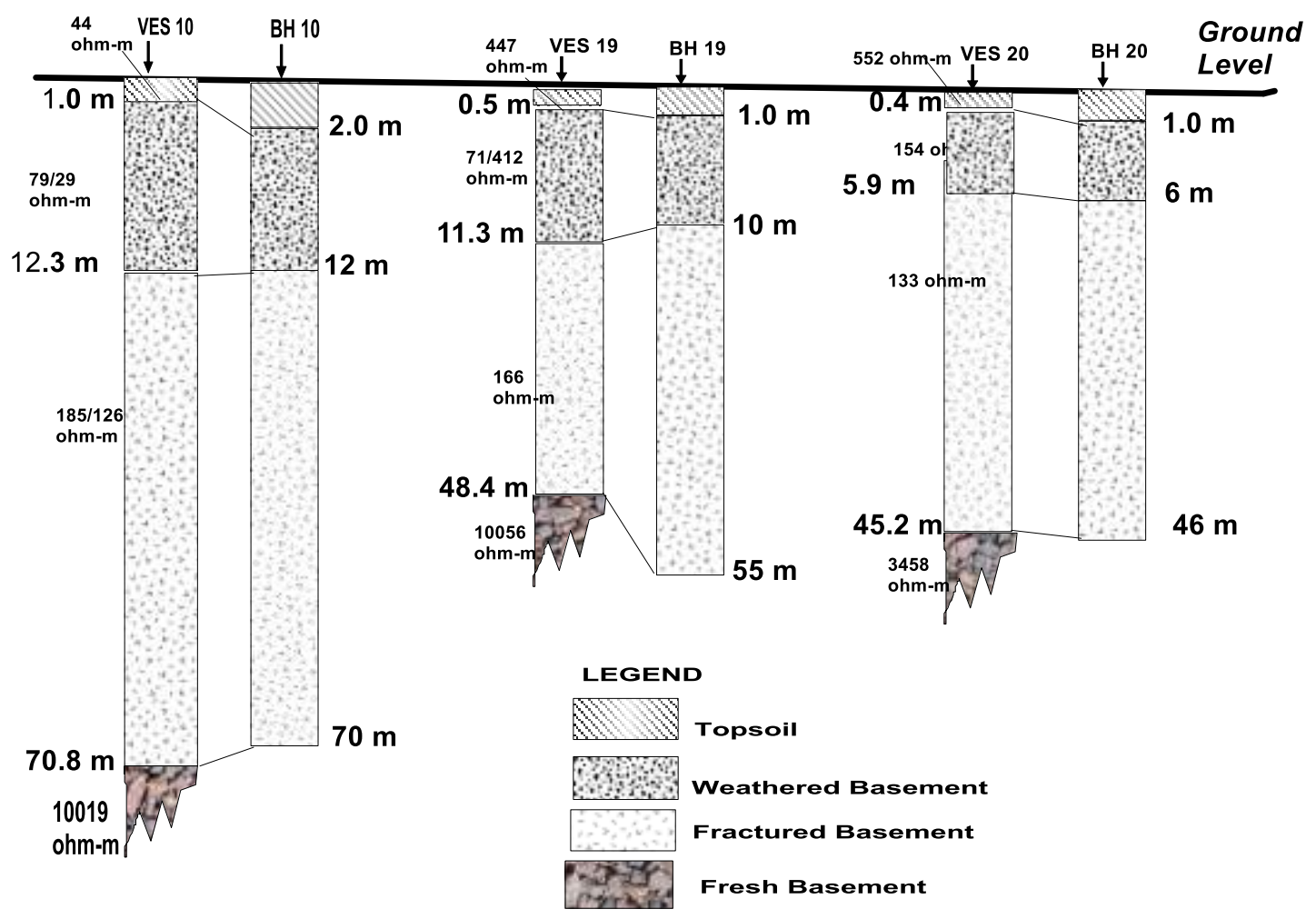

Not Drawn to Scale

Figure 6: Correlation of typical geoelectric and borehole sections

Table 2. Borehole inventories in the study area

\begin{tabular}{|c|c|c|c|c|c|c|}
\hline BH.No & $\begin{array}{l}\text { Depth to } \\
\text { bedrock } \\
\text { (m) }\end{array}$ & $\begin{array}{l}\text { Fracture } \\
\text { intersection } \\
\text { depth }(\mathrm{m})\end{array}$ & $\begin{array}{l}\text { Borehole } \\
\text { depth } \\
\text { (m) }\end{array}$ & $\begin{array}{l}\text { Borehole } \\
\text { yield } \\
\text { (lit/s) }\end{array}$ & $\begin{array}{l}\text { Static water } \\
\text { level } \\
(\mathrm{m})\end{array}$ & $\begin{array}{l}\text { Borehole } \\
\text { (hanging/ } \\
\text { cased down) }\end{array}$ \\
\hline $\mathrm{BH} 3$ & 31.5 & $15-20,30$ & 30 & 0.87 & 5.5 & Hanging \\
\hline $\mathrm{BH} 4$ & Undetermined & 15 & 28 & 0.65 & 6.2 & Hanging \\
\hline BH5 & 24.4 & $6-20$ & 30 & 0.45 & 5.3 & Hanging \\
\hline $\mathrm{BH} 7$ & 15.0 & $10-15$ & 25 & 0.45 & 3.48 & Hanging \\
\hline BH9 & 14.8 & $10-15$ & 28 & 0.42 & 3.6 & Hanging \\
\hline BH10 & 70.8 & $20-65$ & 70 & 2.22 & 4.9 & Hanging \\
\hline BH12 & 28.6 & $6,20,30$ & 55 & 1.15 & 4.3 & Hanging \\
\hline BH13 & Undetermined & $20-50$ & 57 & 1.3 & 5.1 & Hanging \\
\hline BH14 & 57.0 & $15.25,30,40,55$ & 60 & 2.45 & 4.8 & Cased down \\
\hline BH15 & 93.8 & $20,40,50,65$ & 70 & 2.56 & 3.6 & Hanging \\
\hline
\end{tabular}


International Journal of Advances in Scientific Research and Engineering (ijasre), Vol 8 (2), February -2022

\begin{tabular}{|l|l|l|l|l|l|l|}
\hline BH16 & 32.3 & $15,25,30,40$ & 50 & 2.5 & 4.7 & Hanging \\
\hline BH17 & 78.8 & $14,30,50,60$ & 70 & 2.2 & 4.56 & Hanging \\
\hline BH18 & 35.1 & $30,40,50$ & 60 & 1.8 & 5.0 & Hanging \\
\hline BH19 & 48.4 & $11,20,30,40$ & 55 & 2.5 & 4.9 & Cased down \\
\hline BH20 & 39.3 & $11,20,30,40$ & 46 & 2.52 & 4.7 & Cased down \\
\hline
\end{tabular}

The frequency of fractures at depths (Table 3) is further employed to enhance deduction. The distribution reveals $37.2 \%$ of the total fracture intersections within the depth range of $10-20 \mathrm{~m}$, follow by $21-30 \mathrm{~m}$ with $23.5 \%, 31-40(15.6 \%), 41-50$ (9.8\%), $51-60(5.9 \%),<10$ and $>60$ each with 3.9\%. Fracture depths between $10-20$ and $21-30 \mathrm{~m}$ are most prevalent, and are significant for good yields of boreholes in the area. The results further assert that at depth beyond $60 \mathrm{~m}$, the frequency of occurrence of fractures decreases due to lithostatic or overburden pressure that closes up openings and voids at depths. Beyond this depth, the yields of boreholes are wholly retarded. It, therefore, means that the optimum yields from boreholes may have depended to some extent on the combination of the thicknesses of the saturated weathered/partially weathered and fracture depths. The localized multiple micro-fractured layers inter-bedding the thick column of partially weathered basement as suppressed layers in most places may have contributed significantly to the overall drilling depths, groundwater storage and yields. These units as evident from increase penetration rate during drilling may further be appraised to boost the yields of boreholes. The earlier borehole drill depths with yields of $0.42-0.87 \mathrm{l} / \mathrm{s}$ hardly went beyond $30 \mathrm{~m}$ for fracture depths of $15-20 \mathrm{~m}$ as found with $\mathrm{BH} 3-$ $\mathrm{BH} 5, \mathrm{BH} 7$ and $\mathrm{BH} 9$ and numerous others over the years.

Table 3. Frequency distribution of fracture depthsof boreholes in the study area

\begin{tabular}{|c|c|c|c|c|c|c|c|}
\hline $\begin{array}{c}\text { Fracture depth } \\
\text { interval (m) }\end{array}$ & $<10$ & $10-20$ & $21-30$ & $31-40$ & $41-50$ & $51-60$ & $>60$ \\
\hline Frequency & 2 & 19 & 12 & 8 & 5 & 3 & 2 \\
\hline Frequency (\%) & 3.9 & 37.2 & 23.5 & 15.6 & 9.8 & 5.9 & 3.9 \\
\hline
\end{tabular}

\subsection{CONCLUSION}

Combination of the weathered basement and fractured depths remain a basis for a rational choice of optimum drill depths and borehole groundwater yields in a typical basement hitherto hydrogeologically classified as difficult. The regoliths constituted thin aquitards developed on the basement for most shallow boreholes and wells, while the interbedding multiple thin layers of fractured basement coupled with major fracture intersections typically at $10-20,21-30$ and $50-65 \mathrm{~m}$ depths provide additional major groundwater flow/storage to optimize yields of deeper boreholes in the area. Lower yields $<1.0 \mathrm{l} / \mathrm{s}$ of the shallow boreholes are depth - constrained at the instance of the poor index of lithologies exhibited by the sounding results and/or poor resistivity contrast/overshadow effect of the thin fracture beds.

However, degree of hydraulic connectivity of the partially weathered basement/thin interbedding fractured basement unitss in most places may further be assessed as the few deeper boreholes beyond $30 \mathrm{~m}$ depth seemed to have taken advantage of the units to boost groundwater yields. Depths for optimum groundwater yields of $1.15-2.56 \mathrm{l} / \mathrm{s}$ varies between $46-70 \mathrm{~m}$ with a mean of $55.3 \mathrm{~m}$ and are lithologic weathering and fracture depths dependent in this part of the basement terrain. The study is, therefore, a key to any borehole drilling decision where construction of continuous pumping, long-term productive boreholes and water wells are required.

\section{ACKNOWLEDGMENT}

Water and Sanitation, Ondo State Ministry of Water Resources is acknowledged for the release of part of the datasets used for the study.

\section{REFERENCES}

[1] P. Kearey and M. Brooks, 'An Introduction to geophysical exploration', $2^{\text {nd }}$ edition, Blackwell Science Ltd, London, 1991, pp. 73-180, 201-216. 
[2] B. O. Odusanya and U. M. P. Amadi, 'An empirical resistivity model for predicting shallow groundwater occurrence in the Basement Complex water resources’, Journal of Nigerian Association of Hydrogeologists, $\quad$ 1990, vol. 2, pp. 77-87.

[3] A. I. Olayinka and M. O. Olorunfemi, 'Determination of geoelectrical characteristics in Okene area and implication for borehole siting', Journal of Mining and Geol., 1992, vol. 28(2), pp. 403-412.

[4] M. E. Offodile, 'Ground water study and development in Nigeria', Mecon Geology and Engineering Services Ltd., Jos, $2^{\text {nd }}$ Edn., 2002, pp. 1-453.

[5] M. A. Dan-Hassan and M. O. Olorunfemi, 'Hydrogeological investigation of basement terrain in the north central part of Kaduna State, Nigeria, Journal of Mining and Geol., 1999, vol. 35(2), pp. 189-206.

[6] A. E. Bala and E. C. Ike, 'The aquifer of the crystalline basement rocks in Gusua area, northwestern Nigeria', Journal of Mining and Geol., 2001, vol. 37(2), pp. 177-184.

[7] M. O. Olorunfemi, J. S. Ojo, A. I. Olayinka and M. Z. Mohammed, 'Geophysical investigation of a suspected spring in Ajegunle Igoba, near Akure, southwestern Nigeria’, Global Journal of Pure and Applied Sciences, 2001, vol. 7(2), 311 320 .

[8] M. Z. Mohammed and M. O. Olorunfemi, 'Geoelectric investigation of the sedimentary/basement transition zone of part of River Jama'are floodplain in the West Chad Basin, northeastern Nigeria' Science Research $\quad$ Annals, $2007, \quad$ vol. 3(2), pp. 44-60

[9] G. O. Omosuyi, 'Geoelectric assessment of groundwater prospect and vulnerability of overburden aquifer',. Ozean Journal of Applied Sciences, 2010, vol. 3(1), pp. 123-132.

[10] M. Z. Mohammed, T. H. T. Ogunribido and A. T. Funmilayo, 2012 'Electrical resistivity sounding for subsurface delineation and evaluation of groundwater potential of Araromi-Akungba Akoko, southwestern Nigeria'. Journal of Environment and Earth Science, New York, 2012, Vol. 2(7), pp. 29 - 40.

[11] T. L Ajibade,. O. O. Ayeni and M. I. Ahmed, 'Public-private people partnership for sustainable potable water supply in Nigeria'. Journal of Sustainable Development in Africa, 2012, vol. 14(6), pp. 24-72.

[12] B. I. Udoh,. A. U. Utom and S. O. Nwaze, 'Groundwater prospecting in fractured shale aquifer using integrated suite of geophysical methods, Kpiri-Kpiri, Ebonyi State’, Nigeria, Journal of Geosciences, $\quad$ 2012, vol. 2(4), 60-65.

[13] M. Z. Mohammed and M. O. Olorunfemi, 'Modeling depth as a constraining factor for optimum groundwater yield - A case study', Journal of Environment and Earth Science, 2012, vol. 2(10), pp. 1-26.

[14] A. Adesida, A. Y. B. Anifowose and J. S. Ojo, 'A study on basement fracture pattern around Akoko area of southwestern Nigeria for groundwater potential using high - resolution satellite imagery and electrical resistivity’,

Global Journal of Geological Sciences, 2012, vol. 10(1), 59-69

[15] M. B. Aminu, 'Electrical resistivity imaging of a thin clayey aquitard developed on basement rocks in parts of Adekunle Ajasin University campus, Akungba-Akoko, south-western Nigeria'. Environmental Research, Engineering and Management, 2015, vol. 71(1), pp. 47-55.

[16] M. Z. Mohammed, '2D resistivity imaging survey for siting shallow water wells and boreholes' Journal of Applied Physics, 2021, In press - Accepted for publication.

[17] WATSAN, 'Water and sanitation, UNICEF sponsored water project, Ondo state' Ministry of Water Resources, 2004.

[18] AAUA Works and Services, 'Borehole inventories in AAU campus', Akungba Akoko, Nigeria, 2019

[19] FSN, 'National Atlas - Federal Survey of Nigeria', 1 ${ }^{\text {st }}$ Edn, Federal Survey of Nigeria, 1978, pp. 5-11, 136. 
[20] M. A. Rahaman, 'Classification of Nigeria basement complex in southwestern Nigeria', (Kogbe, C. A., Edn.) Elizabethan Publishing Coy, Nigeria, 1988, pp. 41-58.

[21] A. C. Ogunyele, A. O. Oluwjana, I. Q. Ehiola, B. E. Ameh, T. A Salaudeen, 'Petrochemistry and petrogenesis of the Precambrian Basement Complex rocks around Akungba-Akoko, southwestern $\quad$ Nigeria'. RMZ - M\&G, 2019, vol. 66, 173 - 183. DOI: 10.2478/rmzmag-2019-0036.

[22] M. O. Olorunfemi and M. A. Olorunniwo, 'Geoelectric parameters and aquifers characteristics of some parts of southwestern, Nigeria', Journal of Mining and Geology.1985, pp. 100-109.

[23] M. O. Olorunfemi and E. T. Okhue, 'Hydrogeologic and geologic significance of a geoelectric survey at Ile Journal of Mining and Geology, 1992, vol. 28(2), pp. 221-229.

[24]M. Z. Mohammed, 'Hydrogeophysical investigation of parts of the River Jama'are floodplain, West Chad Ife, Nigeria, northeastern Nigeria, Unpublished Ph. D. Thesis, Obafemi Awolowo University, Ile Ife, 2007, pp. 1- 289. 